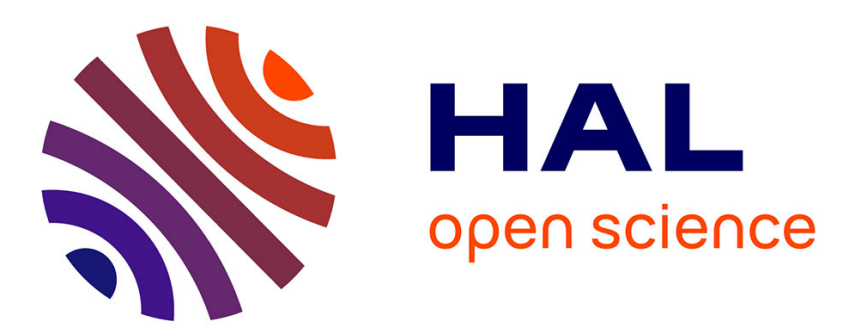

\title{
Comparison of urinary scents of two related mouse species, Mus spicilegus and Mus domesticus.
}

Helena A Soini, Donald Wiesler, Sachiko Koyama, Christophe Féron, Claude Baudoin, Milos V Novotny

\section{- To cite this version:}

Helena A Soini, Donald Wiesler, Sachiko Koyama, Christophe Féron, Claude Baudoin, et al.. Comparison of urinary scents of two related mouse species, Mus spicilegus and Mus domesticus.. Journal of Chemical Ecology, 2009, 35 (5), pp.580-9. 10.1007/s10886-009-9628-2 . hal-00656219

\section{HAL Id: hal-00656219 https://hal.science/hal-00656219}

Submitted on 3 Jan 2012

HAL is a multi-disciplinary open access archive for the deposit and dissemination of scientific research documents, whether they are published or not. The documents may come from teaching and research institutions in France or abroad, or from public or private research centers.
L'archive ouverte pluridisciplinaire HAL, est destinée au dépôt et à la diffusion de documents scientifiques de niveau recherche, publiés ou non, émanant des établissements d'enseignement et de recherche français ou étrangers, des laboratoires publics ou privés. 


\title{
COMPARISON OF URINARY SCENTS OF TWO RELATED MOUSE
}

SPECIES, Mus spicilegus and Mus domesticus

\author{
HELENA A. SOINI ${ }^{1}$, DONALD WIESLER ${ }^{1}$, SACHIKO KOYAMA ${ }^{1}$, CHRISTOPHE \\ FÉRON $^{2}$, CLAUDE BAUDOIN ${ }^{2}$ and MILOS V. NOVOTNY ${ }^{1}$,* \\ ${ }^{1}$ Indiana University, Institute for Pheromone Research, Department of Chemistry, \\ Bloomington, IN 47405, USA \\ ${ }^{2}$ Laboratoire d'Ethologie Expérimentale et Comparée, Université Paris 13, 99 Avenue Jean- \\ Baptiste Clément, F-93430 Villetaneuse, France
}


Abstract - Whereas the house mouse (Mus domesticus) has been studied extensively in terms of physiology/behavior and their pheromonal attributes, the evolutionary related mound-building mouse (Mus spicilegus) has received attention only recently due to its divergent behavioral traits related to olfaction To this date, no hemical studies on urinary volatile compounds were performed on $M$. spicilegus. The rationale for our investigations has been to determine any potential differences in urinary volatiles of intact and castrated $M$. spicilegus male and explore further whether this species could utilize the same or structurally similar pheromones as the male house mouse, Mus domesticus. The use of capillary gas chromatography/mass spectrometry (GC-MS) together with sorptive stir bar extraction sampling enabled such quantitative comparisons between the intact and castrated $M$. spicilegus urinary profiles. Additionally, through GC-MS and atomic emission (sulfurselective) detection, we were able to identify distinct qualitative molecular differences between intact $M$. spicilegus and $M$. domesticus. On one hand, a series of volatile and odoriferous lactones and the presence of coumarin were the unique features of $M$. spicilegus, as was the notable absence of 2-sec-butyl-4,5-dihydrothiazole (a prominent $M$. domesticus male pheromone) and other sulfur-containing compounds. Castration of M. spicilegus males eliminated several substances, including $\delta$-hexalactone and $\gamma$-octalactone, and decreased substantially additional compounds, suggesting their possible role in chemical communication. On the other hand, some other $M$. domesticus pheromones were also found in M. spicilegus urine. These comparative chemical analyses support the notion of metabolic similarities as well as the uniqueness of some volatiles for M. spicilegus, which may have a distinct physiological function in reproduction and behavior. 
Key Words - Mus spicilegus, Mus domesticus, urinary volatile profile, gas chromatography/mass spectrometry, stir bar extraction, pheromones.

*Correspondence: Milos V. Novotny, e -mail: novotny@indiana.edu 


\section{INTRODUCTION}

There is an evolutionary connection between the common house mouse (Mus domesticus) and the mound-building mouse (Mus spicilegus) species, with two pairs of close species and subspecies in the phylogenetic tree, M. musculus domesticus and M. m. musculus in one pair and M. spicilegus and M. macedonicus in the second one (Bonhomme et al., 1984; Sage et al., 1993). The M. domesticus living environment is interwoven to human habitats, whereas $M$. spicilegus species is feral, and in some cases, at least during the summer period, M. spicilegus may live in a close contact with M. m. musculus (Orsini et al., 1983; Sokolov et al. 1998; Simeonovska-Nikolova 2007 ). Additionally, in their social structure and behavior, the $M$. spicilegus have developed far apart from the M. domesticus species. Unlike M. domesticus, M. spicilegus are monogamous (Patris and Baudoin, 1998; Dobson and Baudoin, 2002; Baudoin et al., 2005; Gouat and Féron, 2005) and build co-operatively colonial mounds for overwintering (Orsini et al., 1983; Garza et al., 1997; Poteaux et al., 2008). Moreover, $M$. spicilegus males display intense paternal care (Patris and Baudoin, 2000; Féron and Gouat, 2007).

The $M$. spicilegus species appear to rely on olfaction in their social behavior and mate selection (Patris and Baudoin, 1998; Patris et al, 2002; Heth et al., 2002, 2003). In this species, social and kin recognition through olfactory cues have been observed in several studies (Gouat et al., 1998; Dobson and Baudoin, 2002; Baudoin et al., 2005; Busquet and Baudoin, 2005; Todrank et al., 2005; Colombelli-Negrel and Gouat, 2006). The major mammalian scent sources for chemical communication are sex glands, other skin glands or urine. The salivary androgen-binding proteins (Laukaitis et al., 1997; Talley et al., 2001) and tear fluid peptides (Kimoto et al., 2005) have also been reported as sources of chemical messangers in for M. domesticus. In the house mouse, the urine-mediated chemical signals have been relatively well-characterized over the years (for a review, see Novotny, 2003; Hurst and 
Beynon, 2004). To date, the chemical constituents of various scent sources for the $M$. spicilegus species, used in communication, are still unknown. Behavioral tests have revealed that the odor cues (expected to originate mainly from urine) are used in communication (Patris and Baudoin, 1998; Féron and Gheusi, 2003; Busquet and Baudoin, 2005; Colombelli-Negrel and Gouat, 2006). Thus far, there have been no complementary reports on the chemical nature of such olfactory cues.

The first purpose of this study has been to structurally characterize and quantify individual chemical constituents of the urinary volatile profiles for the intact male $M$. spicilegus against those of castrated animals. The second goal was to compare the findings qualitatively to the previously well characterized male $M$. domesticus urinary compounds.

A quantitative comparison of the intact and castrated $M$. spicilegus male volatile profiles was performed to explore the metabolic end-products which could be produced under the testosterone control. Some of the endocrinologically controlled urinary constituents may act as chemical communication means for various reproductive and social functions. Additionally, the urinary volatile profiles of female and male $M$. spicilegus individuals were qualitatively compared in order to explore the gender roles related to the urine-mediated chemical communication, such as those used in mate selection and individual recognition. This chemical characterization is expected to provide some clues to the observed differences in social and behavioral characteristics between the two species.

To facilitate this study, we used the stir bar aqueous extraction method (Baltussen et al., 1999, 2002), which was followed by solventless sample introduction into a gas chromatograph-mass spectrometer (GC-MS) instrument. This methodology is compatible with screening for volatile organic compounds at low concentrations in biological samples and is well suited for a compound identification and quantitative comparisons (Soini et al., 2005). In addition, a combination of gas chromatography with atomic emission detection 
(GC-AED) was utilized for the highly sensitive sulfur compound profiling. In this report, we also take our previously determined characteristics of the male $M$. domesticus (ICR, C57Black/B6 and C57Black/B10) urinary volatile components and compare them qualitatively with the new M. spicilegus chemical information obtained in this study. Analytical approaches for the M. domesticus and M. spicilegus samples were identical. All analyses were performed in the same laboratory.

\section{METHODS AND MATERIALS}

Experimental Animals Mus spicilegus mice were fifth-generation animals from a population collected in Gyöngyös, Hungary, in October 1999. From the time of their collection, the genealogy of every individual was known and all breeding pairs had been formed in a way to avoid inbreeding. They were bred at the University of Paris 13 under laboratory conditions $\left(20 \pm 1{ }^{\circ} \mathrm{C}\right)$ with a $14: 10 \mathrm{~h}$ light : dark cycle. Food (mouse pellets type M20, Special Diet Services, Witham, Essex, U.K.), water and bedding material (sawdust and cotton) were provided. Mice were weaned at 28 days of age and housed in same-sex sibling groups from 35 days of age. Males and females were 3-6 months old when they were used as urine donors.

For the male-female mouse comparisons, 6 males and 6 females were isolated in standard polycarbonate cages (26 x $16 \mathrm{~cm}$ and $14 \mathrm{~cm}$ high) 1 week before urine collection in order to eliminate the social dominance effect (Féron and Baudoin, 1993, 1998). With the male presence being required to induce sexual receptivity in $M$. spicilegus females (Féron and Gheusi, 2003), we assumed that all the isolated females were in anoestrus.

For the comparisons between intact and castrated males, isolation occurred 3 weeks prior to urine collection. Twenty males were isolated in standard polycarbonate cages $(26 \mathrm{x}$ $16 \mathrm{~cm}, 14 \mathrm{~cm}$ high). Six of them were then castrated under anesthesia induced by an 
intraperitoneal injection of a mixture of ketamine $(100 \mathrm{mg} / \mathrm{kg}$ per mouse) and xylazine (5 $\mathrm{mg} / \mathrm{kg}$ per mouse).

Male M. domesticus urinary volatile profile from inbred ICR albino mice, C57BL /B6 and C57BL /B10 black mice (Jackson Laboratories, Bar Harbor, ME) were used for qualitative comparisons. The data obtained for $M$. domesticus have been previously reported by Harvey et al., 1989 and Novotny et al., 2007.

Urine Collection Animals were introduced individually into a clean polycarbonate cage and surveyed for urination during 5 minutes at maximum. Fresh individual urine was then quickly collected with a syringe and frozen $\left(-20^{\circ} \mathrm{C}\right)$. A preliminary study showed that this was the best process fitted to these very sensitive mice.

Ethical Note The experiments complied with the current French laws (authorization 93-0033 for C. Féron; Laboratory approval was secured from the Prefecture of Seine Saint Denis (prefectorial decree 02-2651), complying with the Association for the Study of Animal Behaviour/Animal Behaviour Society Guidelines for the Use of Animals in Research. Reagents and Analytical Methods All compound identifications were verified through the authentic standards whenever available. Standard compounds were either purchased from Aldrich Chemical Company (Milwaukee, WI) or synthesized in our laboratory according to the previously described synthetic methods for dehydro-exo-brevicomin (Wiesler et al., 1984), sec-butyl-4,5-dihydrothiazole (North and Pattenden, 1990) and 6-hydroxy-6-methyl-3heptanone (Novotny et al., 1999). Twister ${ }^{\mathrm{TM}}$ stir bars $(10 \mathrm{~mm}$ in length, $0.5 \mathrm{~mm}$ film thickness, $24-\mu \mathrm{L}$ polydimethylsiloxane (PDMS) volume) were used as the sorptive extraction devices. They were purchased from Gerstel GmbH (Mülheim an der Ruhr, Germany). Volatile and semivolatile compounds were extracted from $0.2 \mathrm{ml}$ of urine in $20-\mathrm{ml}$ capped glass vials for 60 min with a Twister ${ }^{\mathrm{TM}}$ stir bar. The urine samples were first diluted with 2.0 ml water (high-purity OmniSolv ${ }^{\circledR}$ water, EM Science, Gibbstown, NJ). As an internal 
standard, $8 \mathrm{ng}$ of 7-tridecanone (Aldrich, Milwaukee, WI) was added in $10 \mu \mathrm{l}$ of ethanol to each vial. Stirring speed was $800+$ rpm on the Variomag Multipoint HP 15 stirplate $(\mathrm{H}+\mathrm{P}$ Labortechnic, Oberschleissheim, Germany). Prior to extraction, all glassware was washed with acetone and dried at $80^{\circ} \mathrm{C}$. After extraction, the stir bars were rinsed with a small amount of distilled water, dried gently on a paper tissue, and placed in the TDSA autosampler tube (a product of Gerstel GmbH, Mülheim an der Ruhr, Germany) for the gaschromatographic (GC) or GC-MS analysis. GC equipment for the sulfur compound analysis consisted of an Agilent GC Model 6890 instrument with an Atomic Emission Detector (AED) (Model G2350A from Agilent Technologies, Wilmington, DE) and a Thermal Desorption Autosampler (TDSA, Gerstel). The separation capillary was HP-5MS (30 m x 0.25 mm, i.d., $0.25 \mu \mathrm{m}$ film thickness) from Agilent. Samples were thermally desorbed in a TDSA automated system, followed by injection into the column with a cooled injection assembly, CIS-4. TDSA operated in a splitless mode. Temperature program for desorption was $20^{\circ} \mathrm{C}$ (0.5 $\mathrm{min})$, then $60^{\circ} \mathrm{C} / \mathrm{min}$ to $280^{\circ} \mathrm{C}(10 \mathrm{~min})$. Temperature of the transfer line was set at $280^{\circ}$ C. CIS was cooled with liquid nitrogen to $-60^{\circ} \mathrm{C}$. After desorption and cryotrapping, CIS was heated at $12^{\circ} \mathrm{C} / \mathrm{s}$ to $280^{\circ} \mathrm{C}$ with the hold time of $10 \mathrm{~min}$. CIS inlet was operated in the solvent-vent mode, a vent pressure of $14 \mathrm{psi}$, a vent flow of $30 \mathrm{ml} / \mathrm{min}$, and a purge flow of $50 \mathrm{ml} / \mathrm{min}$. The temperature program in the $\mathrm{GC}$ operation was $40^{\circ} \mathrm{C}$ for $5 \mathrm{~min}$, then increasing to $200^{\circ} \mathrm{C}$ at the rate of $2^{\circ} \mathrm{C} / \mathrm{min}$. The final temperature was held for $10 \mathrm{~min}$. The carrier gas head pressure was $14 \mathrm{psi}$ (flow rate, $1.2 \mathrm{ml} / \mathrm{min}$ ). The GC unit was operated in the constant- flow mode. The emission lines for carbon $(193 \mathrm{~nm})$, sulfur $(181 \mathrm{~nm})$ and nitrogen $(174 \mathrm{~nm})$ were monitored during the atomic plasma emission detection.

The GC-MS instrument used for the compound identification was the Agilent $6890 \mathrm{~N}$ gas chromatograph connected to the 5973i MSD mass spectrometer (Agilent Technologies). The GC column was a narrow-bore capillary with $180 \mu \mathrm{m}$, i.d. x $20 \mathrm{~m}$ DB-5MS $(0.18 \mu \mathrm{m}$ 
film thickness, Agilent Technologies, Wilmington, DE). The inlet head pressure was 12.5 psi for the helium flow of $0.7 \mathrm{ml} / \mathrm{min}$. The system operated in the constant-flow mode. The temperature program was $50{ }^{\circ} \mathrm{C}$ for $2 \mathrm{~min}$, followed by a ramp of $4{ }^{\circ} \mathrm{C} / \mathrm{min}$ to $200{ }^{\circ} \mathrm{C}$ (hold time $1 \mathrm{~min})$. Positive electron ionization $(\mathrm{EI}, 70 \mathrm{eV})$ mode was used with the scanning rate of 4.51 scans/sec over the mass range of 35-350 amu. The MSD transfer line temperature was set at $280{ }^{\circ} \mathrm{C}$. The ion source and quadrupole temperatures were set at $230^{\circ} \mathrm{C}$ and $150^{\circ} \mathrm{C}$, respectively. The TDSA-CIS sample introduction setting was identical to that described above in connection with the GC-AED system, except that the CIS trapping temperature was set at $-80{ }^{\circ} \mathrm{C}$.

Quantitative Evaluations and Statistical Analyses As the basis for quantitative comparisons of urinary chromatographic profiles of the fresh urine collected on plates, the peak area integration was performed and peak areas were normalized by dividing with the peak area of internal standard (7-tridecanone) for each separated component. Either GC-MS total-ion chromatograms (TIC) or selected-ion chromatograms (SIC) obtained after the post-run modification of TICs were used for calculations. Normalized peak areas were statistically evaluated for the intact and castrated mouse groups. Student $t$ test was employed for pairwise comparisons. The sulfur compound profiles from the GC-AED were compared in a qualitative manner between the intact and castrated males. The quantitative data obtained in this study for the male M. spicilegus urine samples was compared semi-quantitatively with the female $M$. spicilegus urine and qualitatively with the male $M$. domesticus urine data obtained in this laboratory previously.

\section{RESULTS}

Male M. spicilegus urinary volatile compound profiles by GC-MS featured more than one hundred components. Approximately 60 compounds showed sufficient spectral intensity and 
purity for the quantitative comparisons. Among these compounds, 46 were identified or partially identified while 10 remain unknown. The compound list is shown in Table 1.

The characteristic feature for the profiles from M. spicilegus was the prominent presence of $\gamma$ - and $\delta$ - lactones, ketones, alcohols and acids. Characteristic urinary components found in M. domesticus are three dihydrofuran compounds (MW 126) originating from a puberty accelerating pheromone, 6-hydroxy-6-methyl-3-heptanone (Novotny et al., 1999) and its lactol form (see Table 1 for 5,5-dimethyl-2-ethyl-4,5-dihydrofuran, Z-5,5-dimethyl-2ethylidenetetrahydrofuran, E-5,5-dimethyl-2-ethylidenetetrahydrofuran). These three furan derivatives were present in male $M$. spicilegus at the level comparable to the M.domesticus data reported earlier (Harvey et al., 1989; Novotny et al., 2007). In the castrated M. spicilegus, the levels were significantly lower $(\mathrm{P}<0.002)$ than in intact $M$. spicilegus males. Another $M$. domesticus pheromone compound, dehydro-exo-brevicomin, also present in female urine in small amounts (Harvey et al., 1989; Jemiolo et al., 1991), was found at lower levels in the intact and castrated male and also in female M. spicilegus urine (data not shown). Castration did not change dehydro-exo-brevicomin levels in M. spicilegus significantly in contrast to the suppressed levels of dehydro-exo-brevicomin in the samples from castrated M. domesticus (Novotny et al., 1980; Harvey et al., 1989). Trace levels of the dominant male mouse pheromone for M. domesticus, $\beta$-farnesene (Harvey et al., 1989), were detected in the intact male M. spicilegus urine, but were not seen in female or castrated animals. N(methylthio)methylaniline was the only identified sulfur compound in the GC-MS TIC profile shown in M. spicilegus profiles, being more abundant in the intact male mouse urine when compared to the mouse urine of castrates $(\mathrm{P}<0.01)$. The representative structures of the main compounds distinguishing the two species are shown in Fig.1.

Castration of M. spicilegus males affected the volatile profiles in three ways: certain compounds, apparently under endocrine control, disappeared, while the levels of other 
compounds increased, and a set of previously undetected compounds became apparent (see Table 1). Fig. 2 illustrates the representative urinary volatile GC-MS TIC profiles for intact and castrated $M$. spicilegus males and intact male $M$. domesticus. In addition to $\beta$-farnesene , castration removed 2-heptanone, $\delta$-hexalactone, $\mathrm{N}$-phenylformanilide and $\gamma$-octalactone from the set of urinary volatiles. Some compound levels decreased significantly after castration, including $\gamma$-hexalactone $(\mathrm{P}<0.02)$ and $\mathrm{N}$ - $($ methylthio $)$ methylaniline $(\mathrm{P}<0.01)$ as shown in Table 1. In contrast, after castration, levels of 2-coumaranone, a unique compound for M. spicilegus, increased significantly $(\mathrm{P}<0.001)$ as demonstrated in Fig. 3. The absolute amounts of 2-coumaranone in castrated male urine were about $300 \mathrm{ng} / \mathrm{ml} \pm 200 \mathrm{ng} / \mathrm{ml}$ (SD, $\mathrm{n}=6$ ), while in the intact mouse urine, the levels were just $2 \mathrm{ng} / \mathrm{ml} \pm 2 \mathrm{ng} / \mathrm{ml}(\mathrm{SD}, \mathrm{n}=14)$. In addition, other constituents, including several lactones, were found at higher levels, and new compounds such as coumarin and several late-eluting lactones appeared in the urine of castrated males (see Table 1). Fig. 4 shows a comparison of selected compound levels affected by castration. Individual variation for some of the compounds appeared relatively large (>70\%, RSD), while some compounds varied only within the range of $12-30 \%$ (RSD) among the sampled individuals. Typically, the variation due to the sampling method was only $5-10 \%(\mathrm{RSD})$.

Qualitative comparisons in the GC-AED sulfur-selective profiles did not reveal any clear differences between intact and castrated animals. Relatively low-level (sub-picogram), sulfur-containing compounds (data not shown) were traced, but could not be identified structurally due to their extremely small representation.

Several of the previously reported $M$. domesticus urinary compounds (Novotny et al., 1990a; 1990b, Novotny et al., 2007) were also present in M. spicilegus profiles including three characteristic dihydrofurans. It is notable that the male dominance signaling pheromone 
compound 2-sec-butyl-4,5-dihydrothiazole and its "structural relative," 2-isopropyl-4,5dihydrothiazole for $M$. domesticus (Novotny et al., 1985), were not detected in the $M$. spicilegus urine. Linear sulfur compounds such as dimethyl disulfide, bis(methylthio)methane and methyl(methylthio)methyl disulfide, typical for M. domesticus (Novotny et al., 2007), were also absent in $M$. spicilegus GC-MS urinary volatile profiles. Furthermore, very few $M$. spicilegus urinary ketones were present compared to those identified in M. domesticus urine (Novotny et al., 2007).

\section{DISCUSSION}

Since castrated male $M$. spicilegus did not show $\beta$-farnesene 2-heptanone, $\delta$-hexalactone, $\mathrm{N}$ phenylformanilide and $\gamma$-octalactone among the urinary volatiles, it is suggested that the metabolic pathways involving these compounds may be under endocrine control. Behavioral tests using these compounds would be necessary to show what are the possible chemosignaling and physiological functions facilitated by these compounds for male and female $M$. spicilegus. Castration affected also most significantly the lactone structural types, thus demonstrating an endocrine feedback for the lactone biosynthesis. There is a strong possibility that some of the lactones may be mediators for chemical communication with the reproduction function. Furthermore, lactone levels were particularly varied among the individual intact males, so that the composition within the lactone compound profile could be related to individual recognition. In their pure form, many of the lactones exhibit fruit- or berry-like aromas (Gatfield et al., 1993), which are relatively subtle odors in human perception, as opposed to the pungent smell in the $M$. domesticus male urine caused by the sulfur-containing compounds. The same unique lactone compounds were found in the female M. spicilegus urine in our qualitative screening (unpublished experiments). 
Lactone biosynthesis involves C-18 hydroxyl fatty acids as precursors, which undergo $\beta$-oxidation steps followed by lactonization (Albrecht et al., 1992). Additionally, 9,10-oleic acid has been reported as a precursor for $\gamma$-dodecalactones in the yeast cultures (Haffner and Tressl, 1996). This may imply that the metabolism of fatty acids leading to urinary lactone end-products could play a prominent role in the $M$. spicilegus metabolism as opposed to $M$. domesticus which show very little presence of urinary lactones. The occurrence of urinary lactones has been previously reported in female and male pine voles (Microtus pinetorum) (Boyer et al., 1989). In female pine voles, $\gamma$-octalactone exhibited the greatest urinary level changes among the volatile compounds after estrogen implantation or ovariectomy.

Other biological sources for lactones have been reported for insects and microorganisms, such as the cephalic gland $\gamma$-octalactone of the giant honeybee workers (Apis laboriosa) (Blum et al., 2000) and $\delta$ - and $\gamma$-lactones emitted by marine Alphaproteobacteria (Dickschat et al., 2005). In these two studies, lactones were hypothesized as potential chemical signaling compounds within the giant honeybee colony and bacterial culture, respectively.

Urinary ketone displays in intact male $M$. spicilegus were interestingly sparse (Table 1). M. domesticus urinary ketones (e.g., 2-heptanone, 6-methyl-5-hepten-3-one, 5-hepten-2one) have been previously found to correlate with the major histocompatibility complex (MHC) mouse haplotypes (Novotny et al., 2007). M. spicilegus originate from Eastern Europe. Several diagnostic genetic loci separate $M$. spicilegus and M. domesticus species (Bonhomme et al., 1984; reviewed in Sokolov et al., 1998). The genes in these loci code for several proteins, which are enzymatically active. The alcohol and malate dehydrogenases, esterases, carbonic anhydrase, mannose and glucose phosphate isomerases are among those proteins. Consequently, some of the distinguishing 
coded enzymes may impact the metabolic pathways leading to the excretion of urinary substances.

In addition to the lactones, urinary coumarin appears as an interesting "metabolic marker compound" for the M. spicilegus species. The presence of coumarin and abundance of 2-coumaranone in the urine of castrated M. spicilegus male also represent distinguishing metabolic pathways from $M$. domesticus. Coumarin could originate from different plants and herbs (reviewed in Bourgaud et al., 2006). In the mammalian systems, coumarin generally exhibits toxic effects and is oxidatively metabolized (detoxified) by the cytochrome P450 mono-oxygenase enzyme system in the liver microsomes (Creaven et al., 1965; Lewis and Lake, 2002). The specific enzyme for coumarin elimination through 7-hydroxylation is CYP2A5 in mouse (Miles et al., 1990). The CYP2A5 enzyme is also known to be inhibited by lactones and 2-coumaranone (Juvonen et al., 1991; 2000). In a study within the $M$. domesticus strains, P450 enzymes have been found genetically altered among these strains (Wood, 1979). Furthermore, a single autosomal gene locus Gpi-1 (glucose phosphate isomerase-1) was found responsible for the differential hydroxylase activity of P450 (Wood and Taylor, 1979). Since Gpi-1 was also found as one of the distinguishing genetic loci between M. spicilegus and M. domesticus (Bonhomme et al., 1984), the vastly different urinary volatile profiles, as seen here, could be due in part to a differential P450 oxidase activity among other metabolic routes. For example, the distinguishing Es-2 loci controlling esterases have been found especially active in the kidney (Ruddle et al., 1969), and thus likely to affect some of the urinary metabolite excretion. However, separate genetic studies and metabolic mapping are necessary to link the genetic sources for the observed metabolic profile differences between $M$. spicilegus and $M$. domesticus, as exemplified by the urinary coumarin levels observed in this study. Furthermore, it seems desirable to investigate how 
could these genetically induced changes in the urinary volatile constituents facilitate chemical communication and social behavior in the "scent world" of the M. spicilegus species.

\section{CONCLUSIONS}

Quantitative comparisons of the urinary volatile profiles for male $M$. spicilegus mice reveal several compounds which have previously shown biological activity as male pheromones in the M. domesticus species. These similarities suggest that the two mouse species carry a certain genetic linkage that may be utilized in chemosignaling. On the other hand, the total absence of the prominent $M$. domesticus male aggression pheromone, 2-sec-butyl-4,5dihydrothiazole, in the $M$. spicilegus urine and the presence of unique $\delta$ - and $\gamma$-lactones and coumarin seem to indicate that the species have developed distinctly separate metabolic pathways involving urinary constituents. As castration of $M$. spicilegus males removed $\delta$ hexalactone and $\gamma$-octalactone among the identified urinary constituents, their testosterone control suggests a possible involvement in chemical communication within the species. Behavioral tests are in progress to define possible roles of several urinary volatile organic compounds in $M$. spicilegus chemical communication. 
Acknowledgements- This work was sponsored jointly by the Lilly Chemistry Alumni Chair and the Indiana METACyt Initiative of Indiana University, funded in part through a major grant from the Lilly Endowment, Inc. as well as the French National Center for Scientific Research and the French Ministry for Higher Education and Research (University of Paris 13). We wish to thank Mr. Kevin Bruce in his assistance with the analyses and data collection, and Professor A. Hefetz for his comments on a previous version of the manuscript. 


\section{REFERENCES}

ALBRECHT, W., HEIDLAS, J., SCHWARZ, M., and TRESSL, R. 1992. Biosynthesis and biotechnological production of aliphatic $\gamma$ - and $\delta$-lactones, pp. 45-58, in T.Teranishi, G.R. Takeoka, and M. Güntert (eds.). Flavor Precursors, Thermal and Enzymatic Conversions, ACS Symposium Series 490, American Chemical Society, Washington.

BAUDOIN, C., BUSQUET, N., DOBSON, F.S., GHEUSI, G., FÉRON, C., DURAND, J.L., HETH, G., PATRIS, B., and TODRANK, J. 2005. Male-female associations and female olfactory neurogenesis with pair bonding in Mus spicilegus. Biol. J. Linnean Soc. 84: 323-334.

BALTUSSEN, E., SANDRA, P., DAVID, F., and CRAMERS, C.A. 1999. Stir bar sorptive extraction (SBSE), a novel extraction technique for aqueous sample: Theory and principles. J. Microcol. Separations 11: 737-747.

BALTUSSEN, E., CRAMERS, C.A., and SANDRA, P.J.F. 2002. Sorptive sample preparation - a review. Anal. Bioanal. Chem. 373: 2-22.

BLUM, M.S., FALES, H.M., MORSE, R.A., and UNDERWOOD, B.A. 2000. Chemical characters of two related species of giant honeybees (Apis dorsata and A. laboriosa): possible ecological significance. J. Chem. Ecol. 26: 801-807.

BONHOMME, F., CATALAN, J., BRITTON-DAVIDIAN, J., CHAPMAN, V.M., MORIWAKI, K., NEVO, E., and THALER, L. 1984. Biochemical diversity and evolution in the genus Mus. Biochem. Genetics 22: 275-303.

BOURGAUD, F., HEHN, A., LARBAT, R., DOERPER, S., GONTIER, E., KELLNER, S., and MATERN, U. 2006. Biosynthesis of coumarins in plants: a major pathway still to be unraveled for cytochrome P450 enzymes. Phytochem. Rev. 5: 293-308.

BOYER, M.L., JEMIOLO, B., ANDREOLINI, F., WIESLER, D., and NOVOTNY, M. 1989. Urinary volatile profiles of pine vole, Microtus pinetorum, and their endocrine dependency. J. Chem. Ecol. 15: 649-662.

BUSQUET, N., and BAUDOIN, C. 2005. Odour similarities as a basis for discriminating degrees of kinship in rodents: evidence from Mus spicilegus. Animal Behav. 70: 9971002.

COLOMBELLI-NEGREL, D., and GOUAT, P. 2006. Male and female mound-building mice, Mus spicilegus, discriminate dietary and individual odours of conspecifics. Animal Behav. 72: 577-583.

CREAVEN, P.J., PARKE, D.V., and WILLIAMS, R.T. 1965. A spectrofluorimetric study of the 7-hydroxylation of coumarin by liver microsomes. Biochem. Journal 96: 390398. 
DICKSCHAT, J.S., WAGNER-DÖBLER, I., and SCHULZ, S. 2005. The chafer pheromone buibuilactone and ant pyrazines are also produced by marine bacteria. J. Chem. Ecol. 31: $925-947$.

DOBSON, F.S., and BAUDOIN, C. 2002. Experimental tests of spatial association and kinship in monogamous mice (Mus spicilegus) and polygynous mice (Mus musculus domesticus). Canadian J. Zool. 80: 980-986.

FÉRON, C., and BAUDOIN, C. 1993. Sexual experience and preferences for odors of estrous females in staggerer mutant mice. Behav. Neurol. Biol., 60:280-281.

FÉRON, C., and BAUDOIN, C. 1998. Social isolation induces preference for odours of oestrous females in sexually naïve male staggerer mutant mice. Chem. Senses, 23: 119-121.

FÉRON, C., and GHEUSI, G. 2003. Social regulation of reproduction in the female moundbuilder mouse (Mus spicilegus). Physiol. Behav. 78: 717-722.

FÉRON, C., and GOUAT, P. 2007. Paternal care in the mound-building mouse reduces inter-litter intervals. Reprod. Fertility Devel. 19: 425-429.

GARZA, J.C., DALLAS, J., DURYADI, D., GERASIMOV, S., CROSET, H., and BOURSOT, P. 1997. Social structure of the mound-building mouse Mus spicilegus revealed by genetic analysis with microsatellites. Molecular Ecol. 6: 1009-1017.

GATFIELD, I.L., GÜNTERT, M., SOMMER, H., and WERKHOFF, P. 1993. Some aspects of the microbial production of flavor-active lactones with particular reference to $\gamma$ decalactone. Chem., Mikrobiol. Technol. Lebensmittel 15: 165-170.

GOUAT, P., PATRIS, B., and LALANDE, C. 1998. Conspecific and heterospecific behavioural discrimination of individual odours by mound-building mice. Comptes Rendus de l'Académie des Sciences Paris, Sciences de la vie 321 : 571-575.

GOUAT, P. and FÉRON, C. 2005. Deficit in reproduction in polygynously mated females of the monogamous mound-building mouse Mus spicilegus. Reprod. Fertility Devel. 17: 617-623.

HAFFNER, T., and TRESSL, R. 1996. Biosynthesis of (R)- $\gamma$-decanolactone in the yeast Sporobolomyces odorus. J. Agric. Food Chem. 44: 1218-1223.

HARVEY, S., JEMIOLO, B., and NOVOTNY, M. 1989. Pattern of volatile compounds in dominant and subordinate male mouse urine. J. Chem. Ecol. 15: 2061-2072.

HETH, G., TODRANK, J., BUSQUET, N., and BAUDOIN, C. 2001. Odour-genes covariance and differential investigation of individual odours in the Mus species complex. Biol. J. Linnean Soc.73: 213-220. 
HETH, G., TODRANK, J., BUSQUET, N., and BAUDOIN C., 2003. Genetic relatedness assessment through individual odour similarities in mice. Biol. J. Linnean Soc. 78: 595-603.

HURST, J.L., and BEYNON, R.J. 2004. Scent wars: the chemobiology of competitive signaling in mice. BioEssays 26: 1288-1298.

JEMIOLO, B., ANDREOLINI, F., XIE, T.M., WIESLER, D., and NOVOTNY, M. 1989. Puberty-affecting synthetic analogs of urinary chemosignals in the house mouse, Mus domesticus. Physiol. Behav. 46: 293-298.

JEMIOLO, B., XIE, T.M., ANDREOLINI, F., BAKER, A.E.M., and NOVOTNY, M. 1991. The $t$ complex of the mouse: chemical characterization by urinary volatile profiles. $J$. Chem. Ecol. 17: 353-367.

JUVONEN, R.O., IWASAKI, M. , and NEGISHI, M. 1991. Structural function of residue209 in coumarin 7-hydroxylase (P450coh). J. Biol. Chem. 266: 16431-16435.

JUVONEN, R.O., GYNTHER, J., PASANEN, M., ALHAVA, E., and POSO, A. 2000. Pronounced differences in inhibition potency of lactone and non-lactone compounds for mouse and human coumarin 7-hydroxylases (CYP2A5 and CYP2A6). Xenobiotica 30: 81-92.

KIMOTO, H., HAGA, S., SATO, K., and TOUHARA, K. 2005. Sex-specific peptides from exocrine glands stimulate mouse vomeronasal sensory neurons. Nature 437:898-901.

LANG, MA., JUVONEN, R., JÄRVINEN, P., HONKAKOSKI, P., and RAUNIO, H. 1989. Mouse liver P450Coh: genetic regulation of the pyrazole-inducible enzyme and comparison with other P450 isoenzymes. Arch. Biochem. Biophys. 271: 139-148.

LAUKAITIS, C.M, CRISTER, E.S., and KARN, R.C. 1997. Salivary androgen-binding protein (ABP) mediates assortative mate selection in Mus musculus. Evolution 51: 2000-2005.

LEWIS, D.F.V., and LAKE, B.G. 2002. Species differences in coumarin metabolism: a molecular modeling evaluation of CYP2A interactions. Xenobiotica 32: 547-561.

MILES, J.S., McLARE, A.W., FORRESTER, L.M., GLANCEY, M.J., LANG, M.A., and WOLF, C.R. 1990. Identification of the human liver cytochrome P-450 responsible for coumarin 7-hydroxylase activity. Biochem. Journal 267: 365-371.

NORTH, M., and PATTENDEN, G. 1990. Synthetic studies towards cyclic peptides. Concise synthesis of thiazoline and thiazole containing amino acids. Tetrahedron 46: 82678290.

NOVOTNY, M., JORGENSON, J.W., CARMACK, M, WILSON, S.R., BOYSE, E.A., YAMAZAKI, K., WILSON, M., BEAMER, W., and WHITTEN, W.K. 1980. Chemical studies of the primer mouse pheromones. pp. 377-390. in D. Müller- 
Schwarze, and R.M .Silverstein (eds.). Chemical Signals in Vertebrates and Aquatic Invertebrates. Plenum Press, New York.

NOVOTNY, M. HARVEY, S., JEMIOLO, B., and ALBERTS, J. 1985. Synthetic pheromones that promote inter-male aggression in mice. Proc. Natl. Acad. Sci. USA 82: 2059-2061.

NOVOTNY, M., HARVEY, S., and JEMIOLO, B. 1990a. Chemistry of rodent pheromones: molecular insights into chemical signaling in mammals, pp.3-21, in D.W. MacDonald, D. Müller-Schwarze, and S.E. Natynzuk (eds.). Chemical Signals in Vertebrates 5. Oxford University Press, Oxford.

NOVOTNY, M., HARVEY, S., and JEMIOLO, B. 1990b. Chemistry of male dominance in the house mouse, Mus domesticus. Experientia 46:109-113.

NOVOTNY, M.V., JEMIOLO, B., WIESLER, D., MA, W., HARVEY, S., XU, F., XIE, T.M., and CARMACK, M. 1999. A unique urinary constituent, 6-hydroxy-6-methyl3-heptanone, has the puberty accelerating pheromone activity in mice. Chem. Biol. 6: 377-383.

NOVOTNY, M.V. 2003. Pheromones, binding proteins and receptor responses in rodents. Biochem. Soc. Transactions 31: 117-122.

NOVOTNY, M.V., SOINI, H.A., KOYAMA, S., BRUCE, K.E., WIESLER, D., PENN, D.J. 2007. Chemical identification of MHC-influenced volatile compounds in mouse urine. I: Quantitative proportions of major chemosignals. J. Chem. Ecol. 33: 417-434.

ORSINI, P., BONHOMME, F., BRITTON-DAVIDIAN, J., CROSET, H., GERASIMOV, S., THALER, L. 1983. Le complexe d'espèces du genre Mus en Europe Centrale et Orientale. II. Critères d'identification, répartition et caractéristiques écologiques. Zeitschr. für Säugetierk. 48 : 86-95.

PATRIS, B., and BAUDOIN, C. 1998. Female sexual preferences differ in Mus spicilegus and Mus musculus domesticus: the role of familiarization and sexual experience. Anim. Behav.. 56, 1465-1470.

PATRIS, B., and BAUDOIN, C. 2000. A comparative study of parental care between two rodent species: implications for the mating system of the mound-building mouse $M u s$ spicilegus. Behav. Proc. 51, 35-43.

PATRIS, B., GOUAT, P., JACQUOT, C., CHRISTOPHE, N., and BAUDOIN, C. 2002. Agonistic and sociable behaviors in the mound-building mice, Mus spicilegus: a comparative study with Mus musculus domesticus. Aggr. Behav., 28, 75-84.

POTEAUX, C., BUSQUET, N., GOUAT, P., KATONA, K., and BAUDOIN, C. 2008. Socio-genetic structure of mound-building mice, Mus spicilegus, in autumn and early spring. Biol. J. Linnean Soc., 93:689-699. 
RUDDLE, F.H., SHOWS, T.B., and RODERICK, T.H. 1969. Esterase genetics in $M u s$ musculus: expression, linkage, and polymorphism of locus Es-2. Genetics, 62, 393399.

SAGE, R.D., ATCHLEY, W.R., and CAPANA, E. 1993. House mouse as models in systematic biology. System. Biol. 42, 523-561.

SCHWENDE, F.J., WIESLER, D., JORGENSON, J.W., CARMACK, M., and NOVOTNY, M. 1986. Urinary volatile constituents of the house mouse, Mus musculus, and their endocrine dependency. J. Chem. Ecol. 12: 277-296.

SIMEONOVSKA-NIKOLOVA, D.M. 2007. Spatial organization of the mound-building mouse Mus spicilegus in the region of northern Bulgaria. Acta Zool. Sinica 53: 22-28.

SOINI, H.A., BRUCE, K.E., WIESLER, D., DAVID, F., SANDRA, P., NOVOTNY, M.V. 2005. Stir bar sorptive extraction: a new quantitative and comprehensive sampling technique for determination of chemical signal profiles from biological media. $J$. Chem. Ecol.. 31: 377-392.

SOKOLOV, V.E., KOTENKOVA, E.V., and MICHAILENKO, A.G. 1998. Mus spicilegus. Mammalian Species 592: 1-6.

TALLEY. H.M., LAUKAITIS, C.M., and KARN, R.C. 2001. Female preference for male saliva: implications for sexual isolation of Mus musculus subspecies. Evolution 45: 631-634.

TODRANK, J., BUSQUET, N., BAUDOIN, C., and HETH, G. 2005. Preferences of newborn mice for odours indicating closer genetic relatedness: is experience necessary? Proc. Roy. Soc. London: Biol. Sci. 272: 2083-2088.

WISLER, D., SCHWENDE, F.J., CARMACK, M., and NOVOTNY, M. 1984. Structural determination and synthesis of a chemical signal of the male state and potential multipurpose pheromone of the mouse, Mus musculus. J. Org. Chem. 49:882-884.

WOOD, A.W. 1979. Genetic regulation of coumarin hydroxylase activity in mice.

Biochemical characterization of the enzyme from two inbred strains and their $\mathrm{F}_{1}$ hybrid. J. Biol. Chem. 254: 5641-5646.

WOOD, A.W., and TAYLOR, B.A. 1979. Genetic regulation of coumarin hydroxylase activity in mice. Evidence for single locus control on chromosome 7. J. Biol. Chem. 254: 5647-5651. 


\section{Figure Legends}

Fig.1. Distinguishing chemical structures of volatile compounds in M. spicilegus and M. domesticus male urine.

Fig 2. Representative urinary (GC-MS total ion current) profiles of A: intact and B: castrated male $M$. spicilegus. C: A comparative profile for male intact M. domesticus.

Fig. 3. Urinary 2-coumaranone levels before and after castration.

Fig. 4. Effect of castration: compound levels significantly reduced in urine after castration. DHF (1-3) dihydrofuran compounds, as indicated in Table 1. 


\section{TABLE 1. COMPARISON OF MALE MUS SPICILEGUS URINARY COMPOUNDS IN INTACT (I) AND CASTRATED ( C ) SAMPLES}

\begin{tabular}{|c|c|c|c|}
\hline Compound & $\begin{array}{l}\text { Retention } \\
\text { time } \\
\text { (min) }\end{array}$ & $\begin{array}{c}\text { Comparison } \\
\text { of levels } \\
\text { I vs C* }\end{array}$ & $\begin{array}{c}\text { Student t-test } \\
\mathrm{P}^{*}\end{array}$ \\
\hline $\begin{array}{l}\text { 5,5-dimethyl-2-ethyl-4,5- } \\
\text { dihydrofuran (DHF 1) }\end{array}$ & 3.52 & $\mathrm{I}>\mathrm{C}$ & 0.001 \\
\hline $\begin{array}{c}\text { Z-5,5-dimethyl-2- } \\
\text { ethylidenetetrahydrofuran(DHF 2) }\end{array}$ & 4.97 & $\mathrm{I}>\mathrm{C}$ & 0.001 \\
\hline 2-heptanone & 5.24 & $\mathrm{C}=0$ & \\
\hline $\begin{array}{c}\text { E-5,5-dimethyl-2- } \\
\text { ethylidenetetrahydrofuran (DHF 3) }\end{array}$ & 5.72 & $\mathrm{I}>\mathrm{C}$ & 0.002 \\
\hline p-cymene & 9.13 & $\mathrm{I}>\mathrm{C}$ & 0.028 \\
\hline 3-octen-2-one & 9.60 & & \\
\hline dehydro-exo-brevicomin (DHB) & 9.93 & & \\
\hline$\gamma$-hexalactone ${ }^{* *}$ & 9.99 & $\mathrm{I}>\mathrm{C}$ & 0.023 \\
\hline acetophenone & 10.46 & $\mathrm{I}>\mathrm{C}$ & 0.013 \\
\hline o-toluidine & 10.61 & & \\
\hline$\delta$-hexalactone ${ }^{* *}$ & 11.37 & $\mathrm{C}=0$ & \\
\hline undecane & 11.76 & $\mathrm{I}>\mathrm{C}$ & 0.01 \\
\hline nonanal & 11.91 & $\mathrm{I}>\mathrm{C}$ & 0.018 \\
\hline phenylacetone & 12.55 & & \\
\hline a lactone $* *$ & 13.38 & $\mathrm{I}>\mathrm{C}$ & 0.001 \\
\hline undecalactone $* *$ & 13.63 & $\mathrm{I}>\mathrm{C}$ & 0.032 \\
\hline 4-ethylphenol** & 13.95 & $\mathrm{I}>\mathrm{C}$ & 0.003 \\
\hline a methyl toluate** & 14.28 & & \\
\hline octanoic acid & 14.39 & & \\
\hline decanal & 15.42 & & \\
\hline unidentified $\mathrm{m} / \mathrm{z} 121 * *$ & 15.63 & & \\
\hline N-phenylformanilide & 15.65 & $\mathrm{C}=0$ & \\
\hline unidentified $\mathrm{m} / \mathrm{z} 140 * *$ & 15.83 & & \\
\hline 2-coumaranone $* *$ & 16.24 & $\mathrm{C}>\mathrm{I}$ & 0.001 \\
\hline a lactone $* *$ & 16.96 & $\mathrm{I}=0$ & \\
\hline$\gamma$-octalactone ${ }^{* *}$ & 17.16 & $\mathrm{C}=0$ & \\
\hline a lactone** & 17.29 & $\mathrm{C}>\mathrm{I}$ & 0.012 \\
\hline nonanoic acid & 17.64 & & \\
\hline 1-decanol & 17.68 & & \\
\hline$\delta$-nonyl- $\delta$-valerolactone*** & 17.82 & & \\
\hline a ketone & 17.9 & $\mathrm{I}>\mathrm{C}$ & 0.036 \\
\hline indole & 18.16 & & \\
\hline coumarin** & 18.35 & $\mathrm{I}=0$ & \\
\hline$\gamma$-nonenolactone ${ }^{* *}$ & 19.77 & $\mathrm{C}>\mathrm{I}$ & 0.048 \\
\hline a lactone $e^{* *}$ & 20.45 & $\mathrm{I}=0$ & \\
\hline an acid** & 20.90 & & \\
\hline undecanol & 21.05 & & \\
\hline $\mathrm{N}-($ methylthio)methylaniline & 21.92 & $\mathrm{I}>\mathrm{C}$ & 0.01 \\
\hline
\end{tabular}




\begin{tabular}{|c|c|c|c|}
\hline Compound & Rt (min) & $\begin{array}{c}\text { Comparison } \\
\text { of levels } \\
\text { I vs C* }\end{array}$ & $\begin{array}{c}\text { Student t-test } \\
\mathrm{P}^{*}\end{array}$ \\
\hline dodecanal & 22.15 & & \\
\hline geranylacetone & 23.31 & & \\
\hline$\beta$-farnesene & 23.47 & $\mathrm{C}=0$ & 0.003 \\
\hline m/z 125 $\delta$-lactone** & 23.68 & $\mathrm{I}>\mathrm{C}$ & \\
\hline unknown** & 23.78 & $\mathrm{I}=0$ & \\
\hline unknown** & 23.97 & $\mathrm{I}=0$ & \\
\hline dodecanol & 24.19 & $\mathrm{I}>\mathrm{C}$ & \\
\hline unknown** & 24.99 & & \\
\hline unknown** & 25.51 & $\mathrm{I}=0$ & \\
\hline dodecanoic acid & 26.87 & & \\
\hline an acid** & 27.34 & $\mathrm{I}=0$ & \\
\hline unknown** & 33.66 & $\mathrm{I}=0$ & \\
\hline unknown** & 34.30 & & \\
\hline palmitic acid & 34.69 & $\mathrm{I}=0$ & \\
\hline unknown** & 37.37 & $\mathrm{I}>\mathrm{C}$ & \\
\hline unknown** & 38.30 & $\mathrm{I}=0$ & \\
\hline N,N-dimethyldodecanamide** & 38.82 & $\mathrm{I}=0$ & \\
\hline
\end{tabular}

* statistical significance for the compound level differences between intact (I) and castrated (C) male M. spicilegus urine (significance $\mathrm{P}<0.05$ accepted) ** unique urinay compounds for M.spicilegus, not found in M.domesticus 
M. spicilegus<smiles>CCC1CCC(=O)O1</smiles>

$\gamma$-hexalactone

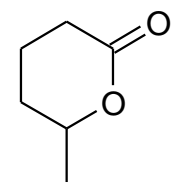

$\delta$-hexalactone<smiles>O=c1ccc2ccccc2o1</smiles>

coumarin<smiles>O=C1Cc2ccccc2O1</smiles>

2-coumaranone

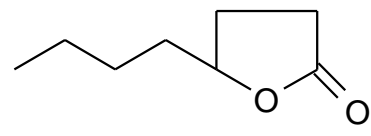

$\gamma$ - octalactone
M. domesticus

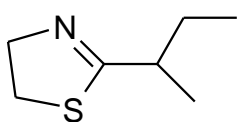

2-sec-butyl-4,5-dihydrothiazole (SBT)

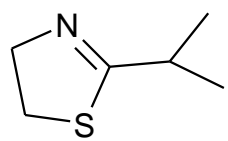

2-isopropyl-4,5-dihydrothiazole (IPT)<smiles>CSSC</smiles>

dimethyl disulfide<smiles>CCC(C)C</smiles>

bis(methylthio)methane

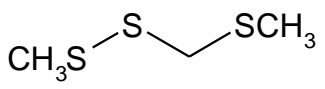

methyl (methylthio)methyl disulfide

Fig.1. 


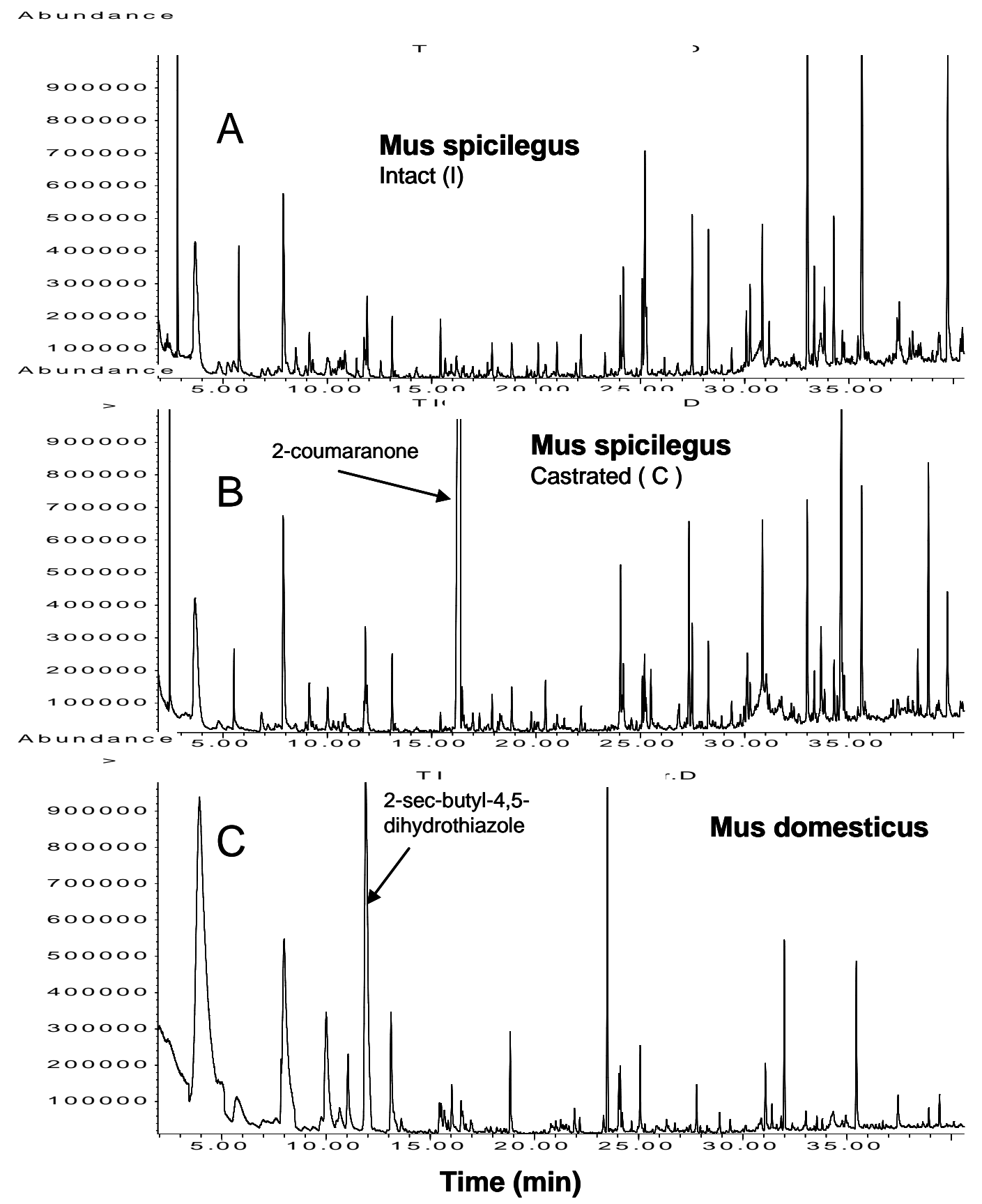

Fig. 2 


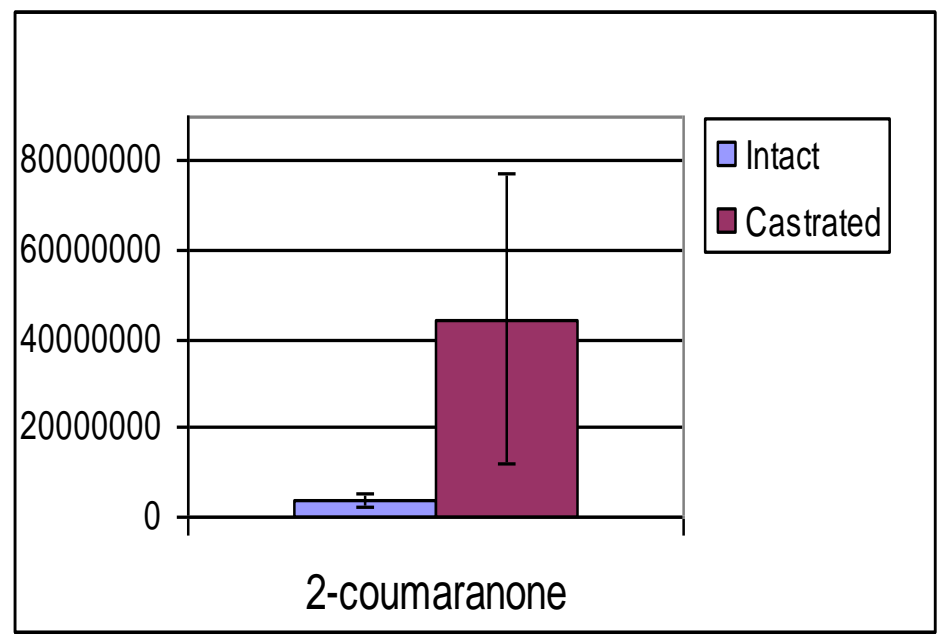

Fig. 3 

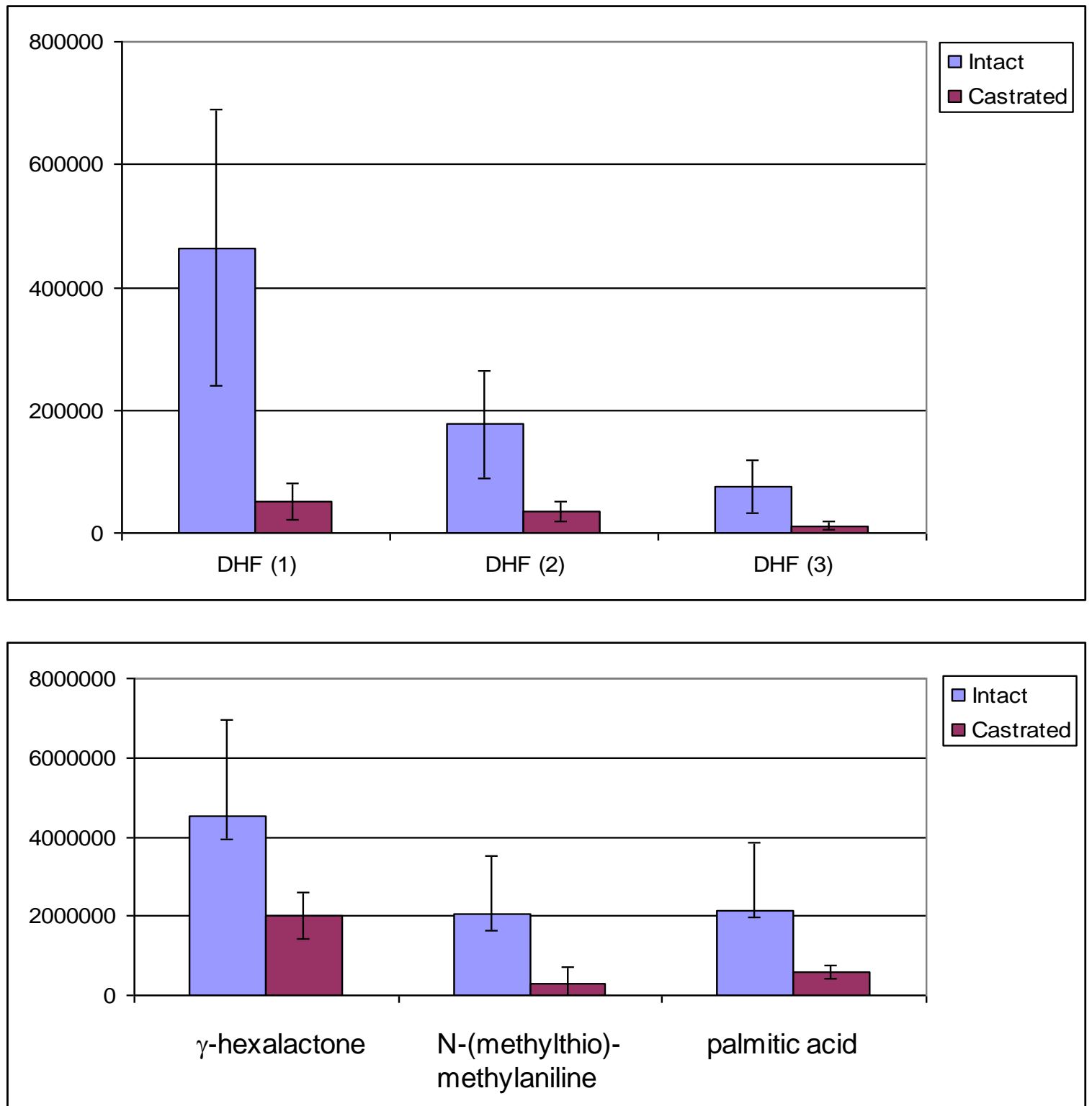

Fig. 4 